\title{
Universiteit
}

Leiden

The Netherlands

\section{University students' revolt, ethnic militia, and violence during political liberalization in Cameroon}

Konings, P.J.J.

\section{Citation}

Konings, P. J. J. (2002). University students' revolt, ethnic militia, and violence during political liberalization in Cameroon. African Studies Review : The Journal Of The African Studies Association, 45(2), 179-204. Retrieved from https://hdl.handle.net/1887/3505

Version: $\quad$ Not Applicable (or Unknown)

License: $\quad$ Leiden University Non-exclusive license

Downloaded from: https://hdl.handle.net/1887/3505

Note: To cite this publication please use the final published version (if applicable). 


\title{
University Students' Revolt, Ethnic Militia and Violence during Political Liberalization in Cameroon
}

\author{
Piet Konings
}

\begin{abstract}
Political liberalization provided space for students at the University of Yaounde to organize and voice their multiple grievances about the poor living and study conditions on campus and the process of "institutional liberalization," blocking their pursuit of upward mobility. The unprecedented degree of violence that accompanied the protracted strike actions during the period 1990-96 may be attributed not only to the persistent refusal of the university authorities and the regime to enter into any meaningful form of dialogue with the students but also to the internal divisions among the students along party and ethno-regional lines. The major lines of division were between "stranger" students closely allied to the radical opposition and the "autochthonous" Beti students closely allied to the regime in power. With the support of the regime, the latter created various militia that resorted to violent forms of ethnic exclusion to re-establish control over "their" university.
\end{abstract}

Piet Konings is a senior researcher at the African Studies Centre, University of Leiden, in The Netherlands. He has carried out extensive research on the political economy, workers, trade unions and rural development in Africa, especially in Ghana and Cameroon, and has published widely in these fields. One of his major current research interests is the politics of Anglophone identity in Cameroon.

The struggle for political liberalization, starting at the end of the 1980s, unleashed an unprecedented wave of student rebellion on university campuses in West and Central Africa (Kpatinde 1991). University students were often in the forefront of these struggles, sometimes with the support of secondary school students, their teachers and other socio-professional groups (Bratton and van de Walle 1992).

Although there is a striking lack of studies on the role of students in the "democratic transition" (Buijtenhuijs and Thiriot 1995), the reasons for their widespread revolt seem to be similar. Political liberalization allowed space for students to voice their longstanding grievances about the deteriorating living and study conditions at most African universities. The lack of basic infrastructure needed to cope with the massive growth in the student population since independence resulted in rapidly falling academic standards (Mbembe 1985; Tedga 1988; Lebeau 1997). The severe economic crisis and subsequent Structural Adjustment Programmes (SAPs) aggravated the situation with an increasing withdrawal of state support for universities, university students and university graduates (Albert 1995; Federici 2000). Governments were compelled to make further cuts in university budgets, to request that students pay tuition fees and additional levies, and to virtually stop recruiting new graduates into already over-sized state bureaucracies. As a result of such state withdrawal, African universities no longer appeared to be serving as centers of elite formation. This process of "institutional liberalization" has been highly resented by the students in their pursuit of upward mobility. ${ }^{1}$ Comparing themselves with preceding generations who could count on getting government jobs because of their degrees, students nowadays see themselves as an "abandoned" or "lost" generation (Cruise O’Brien 1996). Little wonder that they have been inclined to see corrupt and authoritarian regimes as responsible for their predicament and to perceive a "democratic transition" as a necessary precondition for change in society in general and in universities in particular. In Mali, students made a significant contribution to the overthrow of the regime and the introduction of a multi-party system (Smith 1997) but 
in most other African countries student rebellions have been brutally suppressed by the forces of law and order.

In this article, I focus on the student revolt at the University of Yaounde - the only university institution in Cameroon until the 1993 university reforms. While Cameroonian university students share most of the grievances expressed by their counterparts in other West-Central African states, they appear to have played a somewhat different, and to a certain extent exceptional, role in the political liberalization process. Although political liberalization offered them the opportunity to organize to defend their interests, it also tended to divide them along ethno-regional lines. This led to an intensification of the simmering tensions between two groups of students: the "autochthonous" Beti students who tended to support the ruling Cameroon People's Democratic Movement (CPDM) on the one hand, and the Anglophone and Bamileke "stranger" students who were more inclined to support the major opposition party, the Social Democratic Front (SDF), on the other. Given the fact that the University of Yaounde was located in "their" territory, the Beti students claimed control of student politics in "their" university and were determined to combat any organization of "stranger" students that caused trouble on campus and strove for the overthrow of the regime. The growing polarization between these two groups of students, fueled by the regime, ethnic entrepreneurs and the press, gave rise to an explosion of violence and the emergence on campus of a Beti militia engaged in various forms of ethnic exclusion. Unlike student rebellions in other parts of West and Central Africa, unrest and violence on the University of Yaounde campus lasted almost uninterrupted for six years from 1990 to 1996.

In the first section of this article I explore the development of student organization along ethno-regional lines during political liberalization, while the second section presents a detailed report of the 1990-96 student revolt. ${ }^{2}$

\section{Political Liberalization and Student Organization along Ethno-Regional Lines}

After its creation in 1961, the University of Yaounde experienced relatively few student protests until the beginning of the 1990s. Some were politically motivated but most were prompted by the students' frequent worries about bourse et bouffe (grants and food), especially the quality and quantity of food and the number, amount and timely payment of scholarships.

The relative absence of any serious student unrest during the first three decades of the university's existence is understandable. Students undoubtedly belonged among the most privileged of the political system and were constantly told that they would be the future leaders soon to be co-opted into the regime. A university degree gave almost automatic access to one of the many potentially lucrative posts in the expanding civil service or public sector. Even when the supply of graduates became much larger than the demand for them in the 1970s, President Ahmadou Ahidjo (1961-82) and his successor, Paul Biya, continued to create job openings for them in the administration. For example, to alleviate pressures on the labour market, the Biya government recruited 1,500 new graduates in the already over-sized state bureaucracy in 1983 and another 1,700 in 1985 . Moreover, in an attempt to preserve student loyalty following Biya's ascendancy to power in 1982, the government increased both the amount and the number of scholarships in 1984 (Mehler 1993:296). And, if the "carrot" did not keep the students quiet, the authoritarian post-colonial regimes did not hesitate to use the "stick." 
Several factors explain why the students' behavior changed so dramatically at the beginning of the 1990s, manifest in their frequent and protracted strike actions. First and foremost, there was growing dissatisfaction with the deepening crisis within the university and the lack of employment prospects for university graduates. Mockingly, students referred to their university as "the bachelors' cemetery." The number of students increased from 35 in 1961 to 10,000 in 1982 and 41,000 in 1992 (Mehler 1998:59; Mbu 1993:82) but the university infrastructure was able to provide for at most 7,000 students (Anonymous 1991). Lecture rooms, libraries, laboratories and office space for lecturers were inadequate and lacked necessary equipment. The university hostel could offer accommodation to a limited number of students, often on the basis of patronage or ethnic criteria and the vast majority of students were compelled to look for accommodation themselves, often in the so-called "mini-cities" around the university, constructed mostly by entrepreneurs closely connected with the university authorities or the regime. Rooms were rented at exorbitant prices, FCFA 10,000 or more per month, very expensive for students on an average scholarship of FCFA 30,000. Lecturers had a heavy teaching load but poor conditions of service (Ouendji 1996). In addition to badly stocked libraries, this was one of the reasons for frequent sales to students, at vast prices, of stereotyped lecture notes dubbed polycops.

Given the inadequate infrastructure, it is not surprising that the quality of degrees offered by the university continued to fall. Failure rates were extremely high, reaching 80 percent in the Faculty of Law and Economic Science (Anonymous 1991). Poor educational standards further lowered graduates' employment chances. Besides this structural crisis, there was also a moral crisis: large-scale fraud during examinations, and sexual harassment.

Above all, there appears to have been no clear separation between politics and academics. All appointments at the university, from that of the Chancellor right down to messengers and cleaners, were political appointments. Loyalty to the regime appears to have been more important than intellectual merit for a university career (Nyamnjoh 1999). A number of professors close to the regime, for example Mono Ndjana, Fame Ndongo, Bipoum Woum and Eno Belinga, were regularly absent from the university, having been recruited by the regime and the CPDM for information campaigns throughout the country. The administration of the university appeared to be geared predominantly towards political control. National security agents could be found disguised as students constantly spying on students and lecturers. As one student put it, "the so-called scholarship is really a bribe in exchange for freedom of thought and expression” (Gobata 1993:98-99).

The university was administered in an authoritarian manner with little dialogue between the university authorities and the academic staff and students. Unlike some other West and Central African countries such as Senegal (Diop 1992; Bathily et al. 1995), Ghana (Amoa 1977; Oquaye 1996) and Nigeria (Ojo 1995; Lebeau 1997), no student union in Cameroon was allowed to represent and defend student interests. The so-called delegates or student representatives were not elected by the students after 1986 but were appointed by the administration. They are responsible for imposing the decisions of the university authorities upon the students while taking note of those who complain (Dibussi 1991:16; Mbu 1993:107). Worse still, they tended to become informants who pointed out subversives to the regime in times of crisis. Lack of participation in university affairs created the impression among students that revolt was the only avenue to change in the university.

While the deepening crisis in the university was a constant source of frustration among students, the changing economic and political environment in Cameroon had a 
radicalizing effect on them. The economic crisis that hit Cameroon - once one of the most prosperous countries in Africa - in the mid-1980s and the subsequent implementation of a SAP in 1988/89 (Konings 1986a) aggravated the students' predicament. There were no longer any funds available for improving the university infrastructure. There were regular delays in the payment of scholarships, causing many hardships among students, and there was an almost total stop in new recruitment into the state bureaucracy. Like other social strata, students tended to attribute the economic ills and the concomitant process of institutional liberalization to the corrupt and authoritarian Biya regime.

The political liberalization process that started in 1990 was a decisive factor in the student rebellion. ${ }^{3}$ It actually appears to have had an ambivalent impact on the students. On the one hand, it created space for students to organize in defense of their interests but on the other hand, it tended to divide them. The introduction of a multi-party system and the regionalization of political competition (Eyoh 1998) split students along party and ethno-regional lines. Political liberalization even encouraged an obsession with autochthony among students, leading to violent forms of exclusion of "strangers", fueled by the Biya regime in its struggle for survival in multi-party elections (Geschiere and Nyamnjoh 2000; Konings 2001). The major line of division among students became the following: the autochthonous Beti students who tended to support the ruling party, the CPDM, led by President Paul Biya who was himself a Beti versus the Anglophone and Bamileke "strangers" lumped together as "Anglo-Bami" who generally supported the main opposition party, the SDF, led by Anglophone John Fru Ndi. ${ }^{4}$ To fully understand this cleavage and the violence that accompanied the struggle between the two groups of students during political liberalization, it is necessary to point out that animosities between the Beti and Anglo-Bami have a long historical background not only at the University of Yaounde but also in Yaounde and Beti territory as a whole.

There was, first of all, the large-scale migration, set in motion during French colonial rule, from the Grassfields - the region of the Francophone Bamileke (the present West Province) and Anglophone ethnic-related peoples (the present North West Province of Anglophone Cameroon) - to Yaounde and other Beti towns. The Bamileke, renowned in Cameroon for their "entrepreneurial ethos" (Warnier 1993), migrated in large numbers to Yaounde, acquiring more and more land to build their own houses and coming to dominate the city's commercial sector to a large extent. Especially after independence (1960), the local population began to express their fears of becoming overwhelmed by the Bamileke in their own area, evoking tensions between the two groups and, sometimes, violent clashes.

Tensions between the two groups increased after Paul Biya came to power in 1982. While Biya's predecessor, Ahidjo, had constantly emphasized the need for ethnic balance (Ngayap 1993; Nkwi and Nyamnjoh 1997), there is ample evidence to suggest that the Bamileke - besides Ahidjo's own Fulbe ethnic group - enjoyed a privileged position regarding capital accumulation during his presidency. It is generally believed in Cameroon that they owed this privilege to Ahidjo's eagerness to obtain the necessary support of the Bamileke elite in his determined efforts to pacify the Bamileke territory that was, until about 1970, one of the major areas of the Union des Populations du Cameroun (UPC) rebellion against the regime (Joseph 1977). The Beti elite saw the transfer of power from Ahidjo to Biya as simply an opportunity to seize power from the Fulbe and Bamileke and advance their own economic and political interests. Initially encountering great difficulties in consolidating his power (Takougang and Krieger 1998), Biya started to give in to these ethnic pressures. In protest against the increasing Beti monopoly on economic and political power, Bamileke businessmen then withdrew 
their savings from banks and transferred them to informal savings circuits called tontines (Henry et al. 1991). This contributed to the banks' growing liquidity problems and to the economic crisis.

The growing tensions between the Beti and the Bamileke were also manifest in the ethnic discourse and repeated ethnic clashes at the University of Yaounde. Following publication of the book L'idée sociale chez Paul Biya in 1985, there was a fierce debate between its author, Mono Ndjana, a professor of philosophy and one of the most faithful ideologues of the regime, and Maurice Kamto, an eminent professor of law. This intellectual debate between a Beti (Mono Ndjana) and a Bamileke (Maurice Kamto) rapidly developed into an ethnic confrontation. In the course of another debate at the university on March 11, 1987, about the political literature in Cameroon, Mono Ndjana accused some Bamileke colleagues of "ethno-fascism" in the sense that they were exhorting their own ethnic group to end their current marginalization and win political power (Collectif "Changer le Cameroun” 1992:19-25). In reaction, one of the accused, the philosopher Sindjoun Pokam, developed his theory of "mono-fascism.” This term refers not only to the name of his adversary, Mono Ndjana, but also to attempts by one single ethnic group, the Beti, to monopolize power in Cameroon (Pokam 1987). Obviously, such debates resulted in an intensification of the existing tensions between the two groups in the university.

Like the Bamileke, the Anglophones were seen as another threat to Beti power. I have argued elsewhere that the Anglophone minority deeply regrets its vote for reunification with the Francophone majority in 1961, feeling marginalized, exploited and assimilated by the Francophone-dominated state and Francophones as a whole (Konings 1996b; Konings and Nyamnjoh 1997). In the wake of Biya's accession to power in 1982, they began to openly protest against their allegedly second-class citizenship in Cameroon and to call for a return to the federal state or outright secession. The Anglophone students at the University of Yaounde were the first to express Anglophone disenchantment with the Biya regime. Their initiative can be explained by the many hardships they experienced at the university. Though officially a bilingual institute, the University of Yaounde has clearly remained a Francophone institute. The Anglophone students protested when, in September 1983, the Beti Minister of National Education promulgated an order modifying the Anglophone General Certificate of Education (GCE) examination by making it similar to the Francophone baccalaureate. Apparently the order was intended to facilitate the entry of Anglophone students into the country's professional and technical institutes, which were exclusively based on the French system. The Anglophone students, however, interpreted the proposed reform as a subtle attempt by the Francophone-dominated state to assimilate the Anglophone educational system. They maintained that the problem of Anglophone exclusion from the professional and technical institutes in the country could not be solved by assimilation but rather by the creation of institutes based on the English system. Their ensuing demonstrations and boycott of classes met with extreme police brutality (Nyamnjoh 1996a). They used this protest action to voice other grievances including the recent dismissal of Dr Bisong, an Anglophone lecturer in the Faculty of Law and Economics, allegedly for offering one of the few courses in English in the officially bilingual university. ${ }^{5}$ The situation did not calm down until eleven days later when President Biya issued a statement calling on students to return to classes and announcing the setting-up of a commission composed of highly qualified and experienced Anglophones and Francophones to look into the students' grievances.

The greatest shock to the Beti and the regime came in May 1990 when the first opposition party in the country, the SDF, was launched in Bamenda, the capital of the 
North West Province of Anglophone Cameroon. ${ }^{6}$ Leading members of the regime condemned the Anglophones for this treacherous action. The Beti mayor of Yaounde, Emah Basile, referred to the Anglophones as "the enemies in the house." The fact that the SDF rapidly spread its influence among the Anglophones and ethnic-related Bamileke heightened the panic in government circles and hardened Beti attitudes towards the Anglo-Bami, perceiving the latter's alliance as the greatest challenge to their position of power.

In Yaounde and other Beti towns the autochthonous population found it unacceptable that Anglo-Bami "strangers" or "settlers" would try to help the SDF to gain power. As "strangers" they should not try to rule in the home region of their landlords but instead should vote CPDM or else go home and vote for their own party. Newly founded Beti vigilante groups, such as Commando Delta, Direct Action, and the National Front for Beti Liberation, signed highly incendiary tracts, referring to the Anglo-Bami as "exploitative, domineering, unscrupulous, and ungrateful invaders" and calling on them to leave or face the consequences (Collectif "Changer le Cameroun" 1992). On several occasions, Beti mobs and vigilante groups attacked Anglo-Bami property in Yaounde while the security forces stood by indifferently (Nkwi and Socpa 1997). One such occasion was in 1991 when the so-called National Coordination of Opposition Parties and Associations (NCOPA), in which the SDF played a leading role, organized a protracted "ghost town" campaign ${ }^{7}$ to force the Biya regime to agree to a sovereign national conference. Another occasion was during the 1992 presidential elections when the chairman of the SDF, John Fru Ndi, made significant inroads into Yaounde thanks to the large Anglo-Bami diaspora: 39 percent of the votes cast against 52 percent for Paul Biya. Following these fraudulent elections, John Fru Ndi accused Biya of stealing his victory. Yet another occasion was the 1996 municipal elections, which took place a few days after the promulgation of a new constitution promising state protection for minorities and the autochthonous population (Geschiere and Nyamnjoh 2000; Konings 2001).

The autochthony discourse and ethnic exclusion became part and parcel of university life when students started organizing in 1990. On the one hand, there emerged what was initially called the National Coordination of Cameroon Students but later changed its name to the Students' Parliament or simply Parliament. It was by far the largest student union on campus. While the Anglo-Bami students formed the core of its membership and leadership, students from other ethnic groups outside the Beti area also formed part of its membership. Many Parliament members lived in one of the minicities around the university called Bonamoussadi and, particularly during the heyday of student rebellion, they tended to assemble almost daily at their meeting-place at Bassora in Bonamoussadi. Parliament soon came under the influence of the opposition parties, notably the SDF. Parliament members agreed with the opposition that an overthrow of the regime was required to bring about real change in society at large and in the university in particular. The Anglophone members equally championed the establishment of an Anglophone university. Parliament leaders often presented themselves as revolutionaries who were prepared to use all means at their disposal, including demonstrations, strikes and acts of vandalism, should the regime and the university authorities fail to listen to or to give in to their demands.

On the other hand, a Committee for Self-Defense was called into being by the regime to counteract the actions of Parliament. Its leadership and membership was mainly Beti but some members of other ethnic groups were also part of the Self-Defense group. For example, one of its principal leaders, “General” Ngoufack, was a Bamileke. He hailed from the same village as Augustin Kontchou Kouomegni who used to be 
Professor of Political Science at the university before being appointed Minister of Information and Culture and a government spokesman. He and other non-Beti members were recruited by the regime to give the public the impression that the Self-Defense group was not an exclusively Beti affair but an organization of responsible students. Ngoufack was well rewarded for his services and was given a lucrative job in the National Ports Authority after his graduation despite the freeze in public-sector employment.

Most of the Beti members of the Self-Defense group believed that Parliament was out to destroy "their" university and to remove "their" government from power. Others perceived Parliament as a group of vandals set to disturb the academic year and to destroy university property, while claiming that they were defending the rights of the responsible students. Others had just joined the group because they were given cash and, in some cases, free lodgings by the regime in return for their combat with Parliament. Since the Committee for Self-Defense was made up of only a small minority of the students, they were allowed to carry weapons, including clubs, knives and pistols, to attack members and sympathizers of Parliament. They were even alleged to be involved in crimes, such as murders, to incriminate Parliament members.

The Committee for Self-Defense worked closely with the Beti vigilante groups on campus, particularly the self-styled Direct Action group that openly declared that the University of Yaounde was on Beti land and thus should fall under Beti control. It often declared that the Anglo-Bami students should either recognize Beti control or "go home.” Sometimes, however, the Self-Defense group composed of Beti and non-Beti students, appeared to distance itself from this ethnic militia:

\footnotetext{
The Committee for Self-Defense is different from the other vigilante groups because these other groups have objectives, which are unknown. Meanwhile, everyone knows the objectives of our committee and it works in the interest of the majority of students who are regularly admitted into the university. ${ }^{8}$
}

Becoming increasingly aware that it constituted only a minority among the student population, the Self-Defense group was prepared to enter into negotiations with their colleagues from Parliament. For instance, in a circular issued on May 6, 1992, it declared:

\footnotetext{
Together let's save the University of Yaounde.

- Conscious of the fact that violence cannot solve any problem,

- Conscious of the fact that discord among the students is disadvantageous to the representation of their interests, and

- Conscious equally of the fact that we have got the same academic problem, The Committee for Self-Defense demands a dialogue, a debate, with our friends of Parliament. $^{9}$
}

Following the formation of the Committee for Self-Defense and the Beti vigilante groups, which received logistical support from the forces of law and order, Parliament created its own commandos to fight these hostile groups and to protect its members.

\section{Political Liberalization and Student Revolt, 1990-96}

From 1990 to 1996 the University of Yaounde barely functioned, with university life being repeatedly paralyzed by student protest and revolt. During this period there were regular violent confrontations between Parliament on the one hand and the Committee 
for Self-Defense, the Beti vigilante groups and the forces of law and order on the other. In this section, I focus on three such confrontations. The first occurred in 1991 following Parliament's call for a sovereign national conference. The second took place in 1993 after Parliament's protest against the introduction of university tuition fees and the third occurred in 1996 following Parliament's resistance of the university authorities' imposition of special levies on students in addition to tuition fees.

\section{Parliament and the holding of a Sovereign National Conference, 1991}

Relations between the students and the state and university authorities started to deteriorate from 1990 onwards. On March 26, 1990, a number of mostly Anglophone students marched in support of launching the SDF in Bamenda and the introduction of a multi-party system in the country. The government press falsely accused them of having sung the Nigerian national anthem (Ngniman 1993; Kamto 1993). ${ }^{10}$ Subsequently, the gendarmes, usually called ninjas by the students and other sections of the population, harassed and brutalized the students, looted their property and arrested about three hundred of them. ${ }^{11}$ Apparently the students' so-called delegates, appointed by the university authorities, were involved in this oppression and pointed out to the gendarmes the rooms of the Anglophone students and even joined them in torturing their fellow students (Dibussi 1991). Little wonder that this behavior by "their" delegates contributed to the students' pursuit of an autonomous organization. This march by Anglophone students incited disaffection and resentment among the autochthonous Beti population on and off campus, with some Beti landlords threatening to remove Anglophone students from their houses. To forestall any further student protest actions, the regime stationed the ninjas permanently on campus.

Tensions remained high on campus for the rest of the year. In July 1990 students lodged a complaint with the Chancellor, Professor Joel Moulen, that a number of them had been paid FCFA 10,000 less than the amount stipulated in the text regulating their scholarships. Since no further payments were forthcoming, they marched on the Ministry of Higher Education. When the Minister failed to settle the issue, they started mounting roadblocks on campus. Fearing that the matter would escalate, the university authorities then decided to pay the students. ${ }^{12}$ In September of the same year some second and third-year students in the Faculty of Law and Economics protested against mass failures in the examinations ${ }^{13}$ and by the end of November, Anglophone students had started boycotting classes to press home their demands. Undergraduates in the Department of English Language and Literature complained about overcrowding in lecture rooms. English private law students protested about discrimination, bitterly lamenting that some of their courses were in French while French private law students had no courses at all in English. ${ }^{14}$

It was in this context of growing tension on campus and the gradual opening of space for organization during the political liberalization process that the National Coordination of Cameroon Students was formed under the leadership of Benjamin Senfo Tonkam, a Bamileke student. Its first public activity was on August 15,1990, when it addressed an open letter to the Head of State, stressing that higher education in Cameroon was "sick and without repairs," being characterized by "inadequate infrastructures, anachronism and arbitrariness." 15 It further stated that university students in Cameroon were among the most wretched in Africa, being faced with poor nutritional standards, housing conditions and transport facilities, low scholarships, language barriers, and exploitation by their professors. It requested the Head of State look into the matter of growing unemployment rates among university graduates and the 
militarization of the university campus after the May 26, 1990 Bamenda incident. It also appealed to him to reform the university so that it would become a veritable school of tolerance and dialogue and regain its lost credibility. The National Coordination of Cameroon Students was soon to be called Parliament, which became closely allied with the newly created opposition parties, in particular the SDF.

The emergence and increasing politicization of Parliament disturbed the university authorities and the regime. Their worries appeared to be justified when, after some earlier skirmishes (Mehler 1993:297; Mbu 1993), an initially peaceful demonstration by Parliament on April 2, 1991, formed the prelude to a two-month explosion of violence on campus. On that day, Parliament members marched in support of the opposition parties' call for the holding of a sovereign national conference and an unconditional general amnesty for political prisoners and exiles. The government strongly condemned their actions, attributing them to student manipulation by the opposition parties. The Head of State warned the students to remain aloof from politics, insisting that the university was a temple of learning and not a haven of politics: "La politique aux politiciens, l'école aux écoliers." In reaction, Parliament leaders maintained that if the authorities were sincere about purging the university of politics, they should start dissolving all the CPDM branches and youth movements on campus and bar the university population from participating in CPDM rallies and other CPDM propaganda activities (Dibussi 1991). Moreover, they claimed that the holding of a sovereign national conference could make a significant contribution to solving the problems at the university and in society as a whole. As one Parliament leader put it:

\begin{abstract}
A sovereign national conference is a forum for collective self-confession, a platform to point out past mistakes and to elaborate new codes of conduct - a process that will inevitably lead to a positive restructuring of our unadapted educational system and its mediocre university and that will eventually lay the foundation for the resolution of post-university problems such as unemployment. ${ }^{16}$
\end{abstract}

The student demonstrations on 2 April were dispersed by the gendarmes but the following day Parliament members marched again, burning vehicles, including that of the Chancellor, and smashing the windows of the Chancellery. The Chancellor then requested that the security forces protect university property and students who refused to take part in the demonstrations. Subsequently, the gendarmes guarding the campus were reinforced by new troops. This combined force immediately moved into action, spraying tear gas over students in excessive quantities, looting their rooms, raping some of the girls and torturing anyone arrested. The authorities were indifferent to such brutalities. Parliament commandos challenged the security forces daily, throwing stones in intifada-style and then withdrawing as well as chanting liberation songs like "Today may be the last day, we don't know." They also tried to protect students in the residential areas against attacks by the Self-Defense group. They developed a system of whistle signals for meeting each other, attacking, withdrawing and so on. Besides Senfo Tonkam, three other Bamileke leaders of Parliament became well known to the Cameroonian public during this period thanks to the media, namely Corentin Talla, nicknamed "Schwartzkopf," Robert Wanto nicknamed "Colin Powell" and Blaise Yimga Yotchou nicknamed "Abou Nidal."

Assuming that the situation was more or less under control, troops withdrew from the campus on 19 April without notifying the Chancellor. Parliament members used this opportunity to assault those lecturers and students who were hostile to Parliament, leading to renewed occupation of the campus by the security forces. Parliament leaders then decided to halt all activities on campus until further notice and to advise their 
fellow students to leave. Curiously, on 21 April, the leader of Parliament, Senfo Tonkam, who had been hiding in the US embassy, was escorted to the campus by US marine bodyguards to announce the so-called Operation Ghost Campus (Boulaga 1997:92-93).

On 4 May, Parliament held a meeting at the university sports complex approved by the Chancellor. An estimated crowd of 25,000 students attended this meeting chanting the popular freedom song of the famous Cameroonian singer Anne-Marie Ndze. Parliament leaders reiterated their demands for the organization of a sovereign national conference, summed up all the students' grievances and called for solidarity among students (Lisinge undated). After the meeting, some Parliament members were attacked and wounded by Direct Action, the Beti militia linked to the Committee for SelfDefense. On Monday morning, 6 May, Parliament members marched to see the Chancellor, providing him with a report of their meeting and requesting protection against any further attacks by the Beti vigilante groups. In his reply, the Chancellor avoided addressing any of the points raised by the students. The latter then decided to leave and to assemble in the afternoon at their usual meeting place at Bassora to devise future strategies.

One of the unexpected guests at the afternoon meeting was "General" Ngoufack, the principal leader of the Self-Defense group. He told Parliament members that he was attending their meeting without the knowledge of his own group. He then declared his willingness to enter into negotiations with the leaders of Parliament. Although he then left the meeting, rumours were already spreading on campus that he had been "hijacked" by Parliament, which understandably led to commotion in Self-Defense group circles, and among the university authorities and the government. The SelfDefense group reacted swiftly by capturing three members of Parliament with a view to holding them hostage until Ngoufack was freed. In the meantime, the Chancellor had notified the government authorities of the dangerous situation and the government then ordered an end to Parliament's meeting.

The security forces arrived when the students were about to leave the meeting and, without any notice, charged brutally. The Self-Defense group, the Beti militia and the Beti inhabitants of the nearby quarters also attacked fleeing students. Soldiers again invaded students' residences in Bonamoussadi, looting property, raping girls and arresting any student caught up in the violence. Reportedly, 218 students were arrested but there were contradictory reports about the number of deaths, disappearances and injuries. While the private press spoke of several deaths, the government was less than precise in its reports. The Minister of Information and Culture and government spokesman, Augustin Kontchou Kouomegni, began a swift rise to prominence in the regime and notoriety in the opposition by claiming "zéro mort" (no deaths). Realizing that the population was shocked by such an unprecedented degree of violence on campus, on 15 May the Biya government appointed a nine-man committee headed by Chief Justice (retired) Sam Endeley, an Anglophone with close ties to the regime, to investigate the matter. In its final report, the committee was critical of the role of the university authorities and the forces of law and order but it came to the conclusion that there were "no deaths, no rapes, no disappearances." While the opposition strongly contested the committee's conclusions, the government was clearly pleased with the report. Soon after its publication, Endeley was appointed Bakweri Paramount Chief - a position that had been vacant for a considerable period of time (Geschiere 1993).

The day after what came to be known in student circles as the "Bassora Massacre", on May 7, 1991, Parliament leaders protested against these events by declaring a 
boycott of classes for the remainder of the year. On the same day, many members of Parliament left their rooms in Bonamoussadi and other mini-cities around the university.

Renewed brutal charges by the security forces on student residences followed after a student, Ndam Souley who was believed to have been a government informant, was killed by a Molotov cocktail on 15 May. Government and Parliament accused each other of having committed this crime. Being charged with murder and wanted by the police, Parliament leaders such as Schwartzkopf, Colin Powell and Abu Nidal, sought refuge in the building of the EEC representation in Yaounde where they were later refused political asylum. Senfo Tonkam was arrested on 23 May and was subsequently sentenced to six months' imprisonment.

The government was eventually prepared to make some concessions to Parliament to induce them to end Operation Ghost Campus. It first announced that two new universities would be created, one of which would be an Anglophone university as demanded by the Anglophone students. It then dismissed the Chancellor, Joel Moulen, and replaced him with Dr Peter Agbor Tabi, the first Anglophone to occupy this position. When this strategy failed to yield the desired results, the government resorted to intimidation. It threatened students by announcing that anyone not attending lectures would be considered dismissed or having withdrawn from the university. From the end of May onwards students began to return to the university. The university authorities forced the ill-prepared students to sit the end-of-the-year examinations so as not to lose the academic year and their own credibility. Examinations were finally held under tight security.

\section{Parliament and the introduction of tuition fees, 1993}

Like his predecessor, the new Chancellor, Peter Agbor Tabi, appeared not to be interested in any form of regular consultation with Parliament. He became almost obsessed with strengthening control over the students. In a time of deepening crisis when the government claimed that there was no money to improve the university infrastructure and to pay salaries and scholarships regularly, he erected the so-called Berlin Wall to facilitate control over the students' by the security forces, the Committee for Self-Defense and the Beti militia.

It soon turned out that his efforts to maintain control were unsuccessful. By December 12, 1991, Parliament had staged another prolonged strike against the delay in the payment of scholarships. A new round of violence and confrontation between Parliament and its opponents occurred on campus after Parliament's leaders had declared a renewed Operation Ghost Campus. Violence reached a climax in "The Night of the Long Knives” on January 20, 1992, when the ninjas stormed Bonamoussadi, again brutalizing and raping students, looting their property and arresting over 35 of them.

A few months later, Parliament announced that 6 May would be a day of Ghost Campus in honor of the martyrs of May 6, 1991 Bassora Massacre. In the days preceding 6 May the Beti militia were distributing tracts in and around campus, threatening the Anglo-Bami students and admonishing them to go home. In a circular, the Committee for Self-Defense announced that it was going to celebrate its historic victory over Parliament on May 6, 1991. ${ }^{17}$ During the night of 5 May, a Bamileke female student, Guiadem Ange Tekam, the director of the students' newspaper The Voice of the Student, was molested by the security forces, forced to march naked through Bonamoussadi and then detained. She was accused of having distributed tracts calling on students to march on 6 May. On Martyrs' Day itself (6 May), some 15 
Parliament members were subjected after their arrest to dehumanizing and savage treatment by the security forces. They were severely beaten, bathed in mud, their hair shaved with broken bottles, their faces painted with a black substance, and then transferred to some of the newly established torture cells. On 8 May, some 500 thirdyear female students from the Faculty of Law and Economics staged a peaceful protest march to the Chancellery. Their ultimatum to boycott classes until the unconditional release of their colleague, Miss Guiadem Ange Tekam, was simply ignored by the Chancellor, Peter Agbor Tabi.

The new chancellor was to face an even greater student challenge at the beginning of 1993. On January 19, 1993, Professor Titus Edzoa, the then Minister of Higher Education, announced on CRTV the long-expected university reforms. The most important were the following:

- the establishment of six, more manageable, university institutions in the country;

- the introduction of a system of credits for two semesters of 14 weeks each (students needed at least a 70 percent pass rate to be promoted to the next class); and

- students were to pay tuition fees of FCFA 50,000 a year, a sum which could be paid in two installments.

The payment of tuition fees was particularly shocking to the students since the Prime Minister, Simon Achidi Achu, and the Minister of Higher Education, Titus Edzoa, had both declared during the 1992 presidential elections that university tuition fees would not be introduced. While still engaged in the struggle for the regular payment of their scholarships, the students were suddenly told they had to pay for their own university education and forget about their unpaid scholarships. In addition, the students argued that they could not be compelled to pay fees at a time when their parents' incomes had been dramatically curtailed due to drastic cuts in salaries and agricultural commodities and the living and study conditions on campus were so poor. ${ }^{18}$

Immediately after the announcement of the university reforms, the members of Parliament assembled at Bassora where they decided to stage a peaceful demonstration in town and to boycott classes. They then marched into town, chanting anti-Biya songs and setting a huge effigy of Biya ablaze. When they started mounting barricades, the gendarmes attacked them. Some sustained injuries, others were arrested. Forced to withdraw, they staged another demonstration in town the following day where the gendarmes again confronted them with water canons, tear gas, beatings and arrests. Back on campus, they set fire to a Faculty of Science building housing a geology laboratory and the offices of some fifty lecturers.

In a circular issued by Parliament, it was alleged that the Chancellor, Peter Agbor Tabi, then instructed his militia on campus to increase raids on students both on campus and in residential areas. These raids, the circular said, "were intended to brutalize students and destroy their goods so that, intimidated, fewer and fewer students would have the courage to join the boycott of tuition fees.” Agbor Tabi was quoted as saying "blood should flow, if necessary, so that the students either pay their fees or go back to their home provinces to do farm work." ${ }^{19}$ Apparently, the security forces, the SelfDefense group and the Beti militia, which started terrorizing Parliament members and destroying or looting their property, carried out Agbor Tabi's instructions religiously.

Violence reigned on campus for months. During the night of 24-25 April, a secondyear Bamileke student, Collins Djongoué Kamga, was set on fire in his room. He was said to have paid part of his tuition fees against Parliament's instructions. The regime 
was therefore quick to make Parliament responsible for this murder. Even the confession by a Beti member of the Committee for Self-Defense on Radio Africa No. 1 on 30 April that his group was responsible for this heinous crime did not deter the regime from punishing Parliament members. Without further investigation, the Minister of Higher Education then summarily dismissed 35 members of Parliament from the university. An additional list of 17 names was circulating and persons on this list felt in danger (Boulaga 1997:143). In an interview after this incident, the Chancellor declared that the Committee for Self-Defense had every right to protect the interests of the responsible students in view of the unstable situation on campus.

One of the consequences of the mysterious assassination was that students started paying their fees for fear of being executed should they fail to do so. The authorities, which were considered to have ended this protracted strike successfully, were rewarded for their services a few weeks later. Following a cabinet reshuffle, the Minister of Higher Education, Titus Edzoa, was promoted to Secretary-General at the Presidency, one of the most powerful positions in Cameroon, while the Chancellor, Peter Agbor Tabi, moved up into Edzoa’s former post.

\section{Parliament and the imposition of special levies on students, 1996}

Parliament members had vehemently resisted the introduction of the FCFA 50,000 university tuition fee in 1993. They became even more restive when the university authorities began to impose additional levies upon students, including FCFA 5,000 for pre-registration, FCFA 5,000 for medical costs (supposed to cover the costs of X-rays that were never carried out), FCFA 1,000 for transcripts of examination results, and FCFA 1,500 for the use of laboratory facilities in the Faculty of Science. In addition, the cost of participation in the catch-up summer session in September was FCFA 25,000 despite the fact that students could follow no more than four courses during this session. The imposition of some new levies, such as the payment of FCFA 100 for each visit to the library at night, FCFA 50 for studying in one of the lecture rooms at weekends and FCFA 25 for the use of toilet facilities, was seen by the students as provocation.

It was not until 1996 that Parliament leaders laid their hands on the 1993 university reform decrees. They then discovered that the imposition of special levies was not covered by the decrees' text of application. Attempts to meet the new Chancellor, Professor Dominique Obounou Akong, to discuss the issue failed.

Two incidents fueled student unrest and sparked off renewed strike action. The first incident occurred on 16 April when the Dean of the Faculty of Arts, Letters and Social Sciences, Professor Joseph-Marie Essomba, issued a circular canceling the first semester results of some third-year students who had not yet sat all their first-year examinations. It also announced that only students who had paid their tuition fees of FCFA 50,000 would have their results published. The students opposed these directives as being a violation of the text and spirit of the 1993 university reform decrees. They emphasized that these reforms stipulated that a 70 percent pass mark sufficed for promotion to the next class and that tuition fees were payable in two installments. Publication of the first semester results could therefore not be made dependent on payment of the second semester fees. The second incident took place on 2 May when the students were provoked by the arrogant behaviour of the Dean of the Faculty of Science, Professor Amougou Akwa. During a meeting with some of his students in front of the Chancellery he tried to round up the discussion by asking whether there was still another "sponger" (fainéant) who wanted to pose a question. The students saw this as further proof of the fact that the university authorities never took them seriously. 
The next day, 3 May, members of Parliament started demonstrating on campus. They marched to the offices of both deans, chased students and lecturers out of the lecture rooms, mounted roadblocks, shattered windscreens and finally launched an attack on the Registrar's office while chanting anti-chancellor songs in Pidgin English like "papa di suffer, Obounou di chop moni." This signified the start of another protracted student strike. A new batch of Parliament leaders emerged with nicknames like Chairman Savimbi, Etienne Lautier, Fidel Castro and Thatcher, who declared a renewed Operation Ghost Campus. In subsequent days there were frequent confrontations between Parliament commandos and the security forces. Any students who were seen carrying books to or from campus were seized by members of Parliament, "baptized" with dirty water and urine, had their faces smeared with mud, and ordered to return to their rooms.

Describing the new levies as "extortions," some 3,000 members of Parliament marched on 6 May to the office of the Chancellor, Dominique Obounou Akong. During a meeting with some of their representatives, the Chancellor reportedly accused Parliament leaders of wickedness and questioned why they had never gone on strike when his predecessor, Peter Agbor Tabi, their Anglophone brother, imposed the new levies. He was nevertheless prepared to make some minor concessions, including a reduction of the toilet fee from FCFA 25 to FCFA 10 and the library fee from FCFA 100 to FCFA 50. He finally threatened to kill any student caught destroying university property. The students were obviously not satisfied with the outcome of the meeting and held the Chancellor hostage in his office until late in the evening when gendarmes used tear gas and water canons to chase them back to their residential areas. ${ }^{20}$

Following his failure to resolve the dispute, the Chancellor invited the Minister of Higher Education, Peter Agbor Tabi, to visit the campus and calm the students down. The following day, 7 May, the Minister went to the campus accompanied by over 200 gendarmes but his provocative speech aggravated rather than resolved the crisis. He warned the students to resume classes and avoid the consequences of strike action, which he insinuated would be dealt with ruthlessly:

You people already know me and the sanctions I can take against any of you caught striking. If you want to march, go on marching, but I advise you to run rather than to march. If you want violence, I will teach you what it means to love it. ${ }^{21}$

He provoked the already irate students even further with his remark that higher education was not for the poor. The September catch-up session was for those who could pay since it was not compulsory and those who could not afford to pay university dues could as well go home and help their parents on their farms. After all, university enrollment figures were still quite high. As soon as he had left the campus, the security forces started dispersing the students. Using tear gas, water canons and batons they descended on the students, beating, injuring and arresting several of them.

On 8 May, Parliament members marched in protest, chanting liberation songs and resorting to violence "to teach Agbor Tabi a lesson in humility." They burnt down a section of one of the halls used for tutorials and attempted to set one of the lecture rooms ablaze but were chased away by the security forces that fired tear gas at them. They then blocked the free flow of traffic in neighbouring areas by setting on fire old tyres but were again tear gassed into hiding.

Changing their strategy, they decided to present their grievances to the Anglophone Prime Minister, Simon Achidi Achu, the following day. A team of three advisors in the Prime Minister's office received a delegation of six Parliament leaders. The Prime Minister had instructed the team to resolve the immediate demands of the students and 
tell them that he could only receive them after they had resumed classes. The team assured the students that all the arrested students would be released and that the forces of law and order would be withdrawn from campus the day after they resumed classes. It also promised the student delegation that the university authorities would victimize none of the strike leaders. Before the delegation left, the Prime Minister sent it a note in which he wrote: "After the resolution of your immediate demands, I will personally look into the other matters when you resume classes. The rule says obedience before complaint.” Parliament members, however, demanded concrete guarantees for what had been discussed. When these were not forthcoming, they continued to boycott classes. The Prime Minister, in turn, washed his hands of the matter, describing the students as "stubborn kids" who needed to be called to order by the university authorities and the government.

Soon after the failure of this conciliation attempt, the Self-Defense group and Beti vigilante groups were reactivated on campus. In a communiqué, the Self-Defense group described the grievances of Parliament as legitimate but it stressed that the authorities had made concessions that should be reciprocated by the students. It regretted that Parliament preferred to resort to acts of vandalism rather than enter into negotiations with the administration, accusing its opponent of being manipulated by the radical opposition parties. It denounced arson on campus as an Anglo-Bami war against the Beti. In the face of what it described as a "premeditated conspiracy against the Beti and their patrimony," it warned the Anglo-Bami students that "the period of relaxation was over." It exhorted the latter to abandon what it referred to as their "Machiavellian Dance" and to go back and destroy property in their own region. It also resolved "that for every Beti student killed, one hundred Anglo-Bami students would be killed in reprisal." It finally called on lecturers who sympathized with the strike to stop their maneuvers, "for your lives will be in danger and your wives will be raped."22

Despite such threats, Ghost Campus continued. The regime then employed the usual tactics of the stick and the carrot. A number of students, who went to inform the Prime Minister on 14 May that some students were still being detained, were arrested and severely beaten by the ninjas stationed around the Prime Minister's office. A few days later, the Prime Minister published a press release asking students to go back to school and calling on the university authorities to respect the 1993 university reform decrees. Parliament leaders, however, considered this to be a vague text and demanded a text signed by President Biya confirming the Prime Minister's decision.

With the situation getting out of hand, the regime and the university authorities began to use the government-owned media as their negotiating table, proposing all kinds of concessions in these media without ever consulting the students. Parliament members felt that they were being taken for a ride and resorted to renewed violence, burning down another lecture room, beating and wounding a captured military captain, smashing windscreens of university authorities' cars and disrupting the examinations of students at the Advanced Teachers' Training College that had been scheduled to be held on the university campus on 21 May. Several arrests were reported.

On 31 May, Parliament members assembled at Bassora, making new demands as a condition for their resumption of classes. Since the various levies imposed by the university authorities after the 1993 university reform decrees had been described as illegal by the Prime Minister in his press release of 16 May, they requested the reimbursement of all such extorted monies and reiterated their demand for a free catchup summer session. ${ }^{23}$ They called on the authorities to resolve their grievances within 48 hours or face the consequences of what was dubbed Operation Storm Campus, programmed to take place on 3 June. Quoting President Biya's notorious proverb that 
"if you want peace, you should prepare for war" (Ndjana 1997), they cautioned that they would turn into terrorists should their grievances not be met within the deadline. On 3 June, there were severe confrontations between Parliament members and the security forces and the Self-Defense group.

Annoyed that the university authorities had failed to control the situation despite previous assurances, President Biya issued a decree on 5 June announcing the sacking of Chancellor Dominique Obounou Akong and his replacement by Professor Jean Messi Messi who was known as a hardliner.

The new chancellor immediately took a number of far-reaching decisions. He withdrew the various levies and declared that the summer session that year would be free. Some of the levies already paid would be reimbursed. Since students nevertheless continued to boycott classes, he created a new vigilante group composed of nonstudents that started terrorizing the students.

A meeting of the Organization of African Unity (OAU) was to be held in Yaounde on 8 July so the government and the university authorities were anxious to re-establish control over the campus and to organize the second-semester examinations before that date. On 11 June, the Dean of the Faculty of Arts, Letters and Social Sciences issued a circular telling students who wished to sit the second-semester examinations (scheduled to take place on 24 June) to register. On the same day, a ministerial order was promulgated dismissing six Parliament leaders from the university for their role in the strike.

The following day students stormed the campus to revoke the dismissal of their colleagues. One philosophy lecturer, Dr Ernest Menyomo, was beaten and almost lynched. Violent confrontations followed between Parliament members and the security forces, the Self-Defense group and the vigilante group. One of the arrested students, Benjamin Mvogo, was reported to have died the next day as a result of having been tortured. In the following days violent confrontations continued after the vigilante group destroyed maize fields near Bonamoussadi belonging to Anglo-Bami and the security forces raided students' rooms in Bonamoussadi, arresting about 300 students.

The strikers' morale rapidly waned. The arrest and dismissal of their leaders, the reimbursement of some of the levies and the promise of a free summer session, the lengthy nature of the strike, and the wish of most students, especially those in their final year, to sit examinations were decisive factors in Parliament members ending their strike. As a result of the prolonged strike action, students were to sit their examinations having attended few or no classes at all.

\section{Conclusion}

In this study I have shown that the political liberalization process in Cameroon was marked by protracted and violent strike actions on the campus of the University of Yaounde during the period 1990-96. Political liberalization provided space for students to organize and to voice their multiple grievances about the poor living and study conditions on campus and the process of "institutional liberalization", blocking their entry into the circle of the elite. While these conditions were aggravated in the 1990s with the introduction of tuition fees and the imposition of additional levies, the university authorities and the regime nevertheless continued to refuse to enter into any meaningful form of dialogue with the newly established student union.

The unprecedented degree of violence that accompanied these protracted strikes must be mainly attributed to the fact that the political liberalization process tended to 
divide students along party and ethno-regional lines. The major lines of division were between the Anglo-Bami students organized in Parliament and closely allied to the radical opposition and the autochthonous Beti students organized in the Committee for Self-Defense and Beti militia and closely allied to the regime in power. In their fight with Parliament, the latter groups resorted to violent forms of ethnic exclusion to reestablish control over "their" university and to maintain "their" regime in power. Allowed by the regime to be armed, they provided invaluable support to the forces of law and order in the brutal repression of Parliament strikes.

It is interesting to observe that in the aftermath of the 1996 student revolt the Committee for Self-Defense and Beti vigilante groups have been replaced on campus by a new group called PRESBY (or President Biya's Youth). This group, which expresses its unshakable loyalty to President Biya, is mainly composed of university students and other sections of the educated youth either engaged in informal-sector activities or unemployed, including a number of university graduates and dropouts. Although the Beti youth appear to play a dominant role in this new movement, young people from other ethnic groups in search of prebends have also joined the group, thus giving PRESBY a national or multi-ethnic outlook. Recent experience has shown that PRESBY is creating a new recruiting ground for the formation of ethnic militia used by the regime to intimidate and terrorize Parliament members.

\section{References}

Albert, I.O. 1995. "University Students and the Politics of Structural Adjustment in Nigeria.” In T. Mkandawire and A. Olukoshi, eds., Between Liberalisation and Oppression: The Politics of Structural Adjustment in Africa. Dakar: Codesria, 37492.

Amoa, S.A. 1979. University Students' Political Action in Ghana. Tema: Ghana Publishing Corporation.

Anonymous. 1991. "Voici pourquoi les étudiant(e)s de l'Université de Yaounde ont fait grève ou l'incontournable conférence nationale.” Peuples Noirs/Peuples Africains 14 (80): 23-53.

Banock, M. 1992. Le processus de démocratisation en Afrique. Paris: L’Harmattan.

Bathily, A., Diouf, M., and M. Mbodj. 1995. "The Senegalese Student Movement from its Inception to 1989.” In M. Mamdani and E. Wamba-dia-Wamba, eds., African Studies in Social Movements and Democracy. Dakar: Codesria, 368-408.

Bayart, J.-F., Geschiere, P., and F.B. Nyamnjoh. 2001. "Autochtonie, démocratie et citoyenneté.” Critique Internationale 10:177-94.

Boulaga, F. Eboussi. 1997. La démocratie de transit au Cameroun. Paris: L’Harmattan.

Bratton, M., and N. van de Walle. 1992. "Popular Protest and Political Reform in Africa.” Comparative Politics 24:419-42.

Buijtenhuijs, R., and C. Thiriot. 1995. Democratization in Sub-Saharan Africa, 19921995: An Overview of the Literature. Leiden/Bordeaux: ASC/CEAN.

Collectif “Changer le Cameroun”. 1992. Le Cameroun éclaté: anthologie commentée des revendications ethniques. Yaounde: Éditions C3.

Cruise O’Brien, D.B. 1996. “A lost generation?: Youth identity and state decay in West Africa.” In R. Werbner and T. Ranger, eds., Postcolonial Identities in Africa. London: Zed Books, 54-74.

Dibussi, T.1991. “What UniYao Students Really Want.” Cameroon Life 1 (9):16-17. 
Diop, M.C. 1992. "Le syndicalisme étudiant: pluralisme et revendications.” In M.C. Diop, ed., Sénégal: trajectoires d'un état. Dakar: Codesria, 431-77.

El-Kenz, A. 1996. "Youth and Violence.” In S. Ellis, ed., Africa Now: People, Policies and Institutions. London: James Currey, 42-57.

Eyoh, D. 1998. "Conflicting Narratives of Anglophone Protest and the Politics of Identity in Cameroon.” Journal of Contemporary African Studies 16 (2):249-76.

Federici, S. 2000. "The New African Student Movement.” In C.B. Mwara, S. Federici, and J. McLaren, eds., African Visions: Literary Images, Political Change and Social Struggle in Contemporary Africa. Westport: Greenwood Press, 49-66.

Geschiere, P. 1993. "Chiefs and Colonial Rule in Cameroon: Inventing Chieftaincy, French and British Style.” Africa 63 (2):151-75.

Geschiere, P., and F.B. Nyamnjoh. 2000. "Capitalism and Autochthony: The Seesaw of Mobility and Belonging.” Public Culture 12 (2):423-52.

Gobata, R.1993. The Past Tense of Shit (Book One. Limbe: Nooremac.

Henry, A., Tchenk, G.H., and Ph. Guierme-Dieumegard. 1991. Tontines et banques au Cameroun. Paris: Karthala.

Joseph, R.1977. Radical Nationalism in Cameroon: Social Origins of the UPC Rebellion. Oxford: Oxford University Press.

Kamto, M.1993. "Quelques réflexions sur la transition vers le pluralisme politique au Cameroun.” In G. Conac, ed., L'Afrique en transition vers le pluralisme politique. Paris: Economica, 209-36

Konings, P. 1996a. "The Post-Colonial State and Economic and Political Reforms in Cameroon.” In A.E. Fernández Jilberto and A. Mommen, eds., Liberalization in the Developing World: Institutional and Economic Changes in Latin America, Africa and Asia. London: Routledge, 244-65. .1996b. "Le 'problème anglophone' au Cameroun dans les années 1990." Politique Africaine 62:25-34. .2001. "Mobility and Exclusion: Conflicts between Autochthons and Allochthons during Political Liberalization in Cameroon.” African Dynamics 1:16994.

Konings, P., and F.B. Nyamnjoh. 1997. "The Anglophone Problem in Cameroon.” The Journal of Modern African Studies 35 (2):207-29.

2000. "Construction and Deconstruction: Anglophones or Autochtones?” The African Anthropologist 7 (1):207-29.

Kpatinde, F. 1991. “Que veulent les étudiants? ” Jeune Afrique 1593 (11-16 July):2224.

Lebeau, Y. 1997. Étudiants et campus du Nigéria. Paris: Karthala.

Lisinge, A.N. undated. The Philosophy behind the University Crisis. No publisher mentioned.

Mbembe, A. 1985. Les jeunes et l'ordre politique en Afrique noire. Paris: L'Harmattan.

Mbu, A.N.T. 1993. Civil Disobedience in Cameroon. Douala: Imprimerie Georges Freres.

Mehler, A. 1993. Kamerun in der Ära Biya. Hamburg: Institut für Afrika-Kunde.

.1997. “ Cameroun: une transition qui n’a pas eu lieu.” In J.-P. Daloz and P. Quantin, eds., Transitions démocratiques africaines: dynamiques et contraintes (1990-1994). Paris: Karthala, 95-138.

.1998. "Cameroun and the Politics of Patronage.” In D. Birmingham and Ph.M. Martin, eds., History of Central Africa: The Contemporary Years since 1960. London: Longman, 43-65. 
Monga, Y. 2000. “'Au Village': Space, Culture and Politics in Cameroon.” Cahiers d'Études Africaines 160 (XL-4):723-49.

Mukong, A., ed. 1990. The Case for the Southern Cameroons. Uwani-Enugu: Chuka Printing Company.

Ndjana, H. Mono.1985. L'idée sociale chez Paul Biya. Yaounde: University of Yaounde.

1997. Les Proverbes de Paul Biya. Yaounde: Éd. du Carrefour.

Ngayap, P.B. 1983. Cameroun: Qui gouverne? Paris: L'Harmattan.

Ngniman, Z. 1993. La démocratie emballée. Yaounde: Éd. Clé.

Nkwi, P.N., and F.B. Nyamnjoh. 1997. Regional Balance and National Integration in Cameroon: Lessons Learned and the Uncertain Future. Leiden/Yaounde: ASC/ICASSRT.

Nkwi, P.N., and A. Socpa. 1997. "Ethnicity and Party Politics in Cameroon: The Politics of Divide and Rule." In P.N. Nkw and F.B. Nyamnjoh, eds., Regional Balance and National Integration in Cameroon: Lessons Learned and the Uncertain Future. Leiden/Yaounde: ASC/ICASSRT, 138-49.

Nyamnjoh, F.B. 1996a. The Cameroon GCE Crisis: A Test of Anglophone Solidarity. Limbe: Nooremac. .1996b. Mass Media and Democratisation in Cameroon. Yaounde: Friedrich-Ebert Foundation. .1999. "Cameroon: A Country United by Ethnic Ambition and Difference." African Affairs 98 (390):101-18.

Nyamnjoh, F.B., and M. Rowlands. 1998. "Elite Associations and the Politics of Belonging in Cameroon.” Africa 68 (3):320-37.

Ojo, J.D. 1995. Students’ Unrest in Nigerian Universities. Ibadan: Spectrum Books.

Oquaye, M. 1996. "Youth, Politics and Society in Ghana." In F.K. Drah and M. Oquaye, eds., Civil Society in Ghana. Accra: Friedrich-Ebert Foundation, 163-202.

Ouendji, N.N. 1996. “ Cameroon : 'Mined' Campuses and Muzzled Staff.” In Codesria, The State of Academic Freedom in Africa 1995. Dakar: Codesria, 121-32.

Pokam, S. 1987. La philosophie politique trahie: le monofascisme. Paris: Silex.

Smith, Z.K. 1997. "From Demons to Democrats: Mali's Student Movement 19911996." Review of African Political Economy 72:249-63.

Takougang, J., and M. Krieger. 1998. African State in the 1990s: Cameroon's Political Crossroads. Boulder: Westview Press.

Tedga, A.J.M. 1988. L'enseignement supérieur en Afrique noire francophone: la catastrophe? Paris: L'Harmattan.

Warnier, J.-P. 1993. L'esprit d'entreprise au Cameroun. Paris: Karthala. 


\section{Notes}

1. I am grateful to Domenic Boyer for this suggestion.

2. The article is based on several interviews held at the University of Yaounde between 1991 and 1998. I also received written reports of the strikes by students and consulted a large number of newspapers and journals.

3. There is an extensive literature on the political liberalization process in Cameroon. See, for instance, Banock 1992; Ngniman 1993; Konings 1996a; and Takougang and Krieger 1998. In my article I focus only on a few aspects.

4. The name "Beti", like other ethnic labels such as "Anglo-Bami", is a historical construct. Beti identity was shaped from the crystallization of a myriad of ethnic groups in the forest region of the Center and South Provinces and, to a lesser extent, the East Province that was provoked by Paul Biya's accession to power in 1982 and subsequent attempts by the opposition to unseat him. Indeed, the present regime's ethnic policies have been highly instrumental in creating a wider sense of ethnic identity and unity. See Bayart et al. 2001; and Monga 2000.

5. Petition of English-speaking students, University of Yaounde, to the Minister of National Education, dated 19 November 1983, reproduced in Mukong 1990: 26.

6. After the massive rally to launch the SDF on 26 May 1990 had ended in the death of six young Anglophones, the state-controlled media tried to deny government responsibility for this bloody event and to distort the facts. See Ngniman 1993; and Nyamnjoh 1996b: 26-27.

7. The "ghost town" (villes mortes) campaign was essentially a civil disobedience campaign, covering the period April 1991-January 1992. During this time the radical opposition issued calls, ultimatums and tracts to ask the public to immobilize the economy by staying indoors, blocking streets, refusing to pay taxes and bills, and boycotting markets and offices. These protests were to be intensified after President Biya, in what observers have termed his firmest and most provocative speech ever, declared on 27 June 1991 that "a sovereign national conference was pointless in Cameroon" and that he would maintain order at all costs. In the ensuing repression the security forces killed two to three hundred demonstrators and the Biya regime placed seven of the country's ten provinces under military control. Significantly, the "ghost town" campaign was not backed in the Beti territory.

8. $\quad$ Quoted in Lisinge (undated): 48.

9. Ibid., p.46.

10. Following the partitioning after World War I of the erstwhile German Kamerun Protectorate into French and English mandate/trust territories, Anglophone Cameroon was administered as an integral part of Nigeria until the 1950s when it attained a quasi-regional status (1954) and later full regional status (1958) within the Federation of Nigeria. Due to the growing dissatisfaction of the Anglophone minority with their alleged recolonization by the Francophone majority, the regime regularly accused Anglophones of secessionist tendencies, striving to rejoin Nigeria.

11. Jeune Afrique, June 11, 1990, p.17.

12. Cameroon Post, July 31- August 17, 1990, p.6.

13. Ibid., October, 4-18, 1999, pp.1 and 7.

14. Ibid., November 26-December 3, 1990, p.10.

15. Ibid., November 19-26, 1990, p.1.

16. Quoted in The Messenger, April 18, 1991, p.4.

17. See Cameroon Today, May 25, 1992, p.6, and Lisinge (undated): 43-45.

18. Le Messager, February 2, 1993, p.16.

19. The Herald, May 5-12, 1993, p.1.

20. The Herald, January 3-5, 1997, p.8.

21. Ibid., and May 13-15, 1996, pp.1-3.

22. The Herald, May 13-15, 1996, p.2.

23 The Herald, June 3-5, 1996, p.3. 